\section{Research Article}

(c) 2021 Baidowi et al. This is an open access article licensed under the Creative Commons Attribution-NonCommercial 4.o International License (https://creativecommons.org/licenses/by-nc/4.o/)

\title{
Promoting Qur'anic Verses That Reject Violence
}

\author{
Ahmad Baidowi ${ }^{\text {* }}$ \\ Irwan Abdullah ${ }^{2}$ \\ Saifuddin Zuhri Qudsy ${ }^{1}$ \\ Nurun Najwah ${ }^{1}$ \\ ${ }^{1}$ Universitas Islam Negeri Sunan Kalijaga Yogyakarta, Jl. Laksda Adisucipto, \\ Papringan, Caturtunggal, Kec. Depok, Kabupaten Sleman, \\ Daerah Istimewa Yogyakarta 55281, Indonesia \\ ${ }^{2}$ Universitas Gadjah Mada Yogyakarta, Bulaksumur, \\ Caturtunggal, Kec. Depok, Kabupaten Sleman, \\ Daerah Istimewa Yogyakarta 55281, Indonesia \\ ${ }^{*}$ Corresponding Author
}

DOI: https://doi.org/10.36941/ajis-2021-0150

\begin{abstract}
This article highlights the mistaken paradigms that underpin the use of Islam to justify violence and terrorism. Its exploration of the Qur'an shows that Islam emphasizes peaceful values and promotes nonviolent approaches; this study, thus, differs from previous ones that have argued Islam's emphasis on peace based on a deconstruction of verses with violent implications, thereby challenging religious violence and violence perpetrated in religion's name. This study analyses the content of the Quranic verses that emphasize Islam's openness and friendliness, prohibit acts of violence and narrate the peaceful resolution of problems as well as mitigating conflict. The analysis of these patterns of Quranic verses shows Islam's alignment with the values of peace and, conversely, disapproval of violence. This exploration of the non-violent values offered by the Qur'an thus offers an important complement to the existing literature on peace and Islam. This study, thus, emphasizes the strategies to promote non-violence which are universal values of the Qur'an.
\end{abstract}

Keywords: Qur'an, non-violence, peace, content analysis, exegesis

\section{Introduction}

Islam has often been perceived as a violent religion, with the Qur'an being viewed as a text that promotes violent behavior (Esposito, 2015). According to Global Terrorism Index, released annually by the Institute for Economics and Peace, between 2000 and 2014 there has been a significant increase in acts of terrorism and violence; the majority of these incidents have occurred in majorityMuslim countries. Religious and sectarian conflict has been similarly widespread. Perpetrators frequently legitimize their acts of violence by citing religion (Volk, 2020). Venkatraman (2007) writes that the Qur'an permits violence where necessary to uphold Islam and its law. Mistaken 
interpretations of such components, however, are not only inappropriate, but ultimately detrimental to Muslims as they result in significant stigmatization (von Sikorski et al., 2018). Some western scholars who are hostile towards Islam often mention the "sword verses" (Qur'an 9:5) as "proof" that Islam is inherently violent (Pipes, 1983). As noted by Holmes (2017), the discourse of Islamic terrorism implies that violence is an integral part of Muslim society, as the very term Islamic terrorism suggests a causal link between Islamic beliefs and terrorist actions. This discourse frames Islam as a source of significant problems (Holmes, 2017).

To date, studies have placed little emphasis on the non-violent and peaceful teachings of Islam. Rather, studies have fallen into two main categories. First, various acts of violence are linked with their perpetrators' Muslim faith (Chapman, 2017; Dornschneider, 2010; Spruyt \& Elchardus, 2012; Steven Fish et al., 2010; Venkatraman, 2007). Following Venkatraman (2007), discussion of Muslims' involvement in terrorism and conflict have produced heated academic debate. Second, Studies that examine the Islamic doctrines and values that allow violence (Heller, 2015; Saiya, 2017; Sukma, 2011; von Sikorski, Matthes, \& Schmuck, 2018). Heller (2015) notes that several elements of the Qur'an, as well as the hadiths (the collected words and deeds of the Prophet Muhammad), contain violent elements that have been used to justify violence and terrorism; indeed, Qur'anic verses may be deliberately interpreted to justify acts of violence (Aisyah, 2012; Holbrook, 2010; Ibrahim \& Abdalla, 2010; Muluk et al., 2013; Venkatraman, 2007). In both categories, scholars tend to position religion as a source of problems.

This article seeks to provide another perspective, one in which Islam and its non-violent teachings are emphasized. More specifically, this article examines the verses that highlight social adhesion and prohibit detrimental actions. In doing so, it seeks to prove that Islam is a religion of peace wherein acts of violence must be rejected as not reflecting the teachings and values of Islam and the Qur'an. It makes three points: first, there are religious values and tenets that promote nonviolence; second, there are jurisprudential bases for embracing non-violence; and third, there are Qur'anic verses that promote non-violent approaches to conflict resolution. All of these points challenge the exegeses that legitimize and justify acts of violence with reference to the Qur'an. In this manner, this study highlights Islam as a religion of peace that celebrates differences and rejects religious violence and conflict. Besides, this study emphasizes the strategies to promote the nonviolence which are universal values of the Qur'an. This point distinguishes this article from the previous studies.

This article's arguments are built upon concrete evidence that Islam rejects violence. First, Islam's rejection of violence is evidenced through religious statements (i.e. Qur'anic verses) that emphasize Islam's openness and friendliness. Second, Islam's emphasis on non-violence is evidenced in its prohibition and regulation of particular human behaviors, as justified by the need to maintain peace. Islam staunchly prohibits acts of violence and severely punishes any transgressions; as such, it does not tolerate violence. Third, Islam's rejection of violence is evidenced in Qur'anic verses oriented towards the peaceful resolution of problems as well as mitigating conflict. Through these verses, the Qur'an staunchly rejects conflict and violence, offering instead non-violent and solution-oriented approaches such as mediation.

\section{Review of the Literature}

\subsection{Use of Religion to Justify Violence}

Pratt (2010) defines violence as any act that stimulates, threatens, or causes injury, be it physical, written, or verbal. A similar definition is offered by Setiawan et al. (2020). For Stewart and Strathern (in Pratt, 2010), meanwhile, violence refers to a dangerous act that legitimizes conflict and contestation. As such, Widiyanto (2017) writes that any correlation between religion and violence may be seen from two perspectives: the potential for violence to originate from within religious structures, and the potential for violence to originate from within religious communities. In the 
current era, religious violence is often replete with religious symbols and justified by religious values and norms. Huntington (2001), similarly, describes contemporary global politics as entrenched in an "Islamic war" and argues that Muslims fight amongst themselves, and with other religious communities, far more than the practitioners of any other faith. Huntington argues that many ongoing conflicts-the global war on terrorism, as well as several guerilla wars, civil wars, and international wars-are rooted in the "rise of an Islamic awareness" (in Karakaya, 2015). Islam has become closely identified with the politics of violence, and attributes this to the prevalence of Muslim terrorists in the past few decades (Kumar, 2010; Munson 2013).

Ostebo (2012) writes that the religious violence perpetrated by Muslims may be attributed to their efforts to assert their religious preferences as well as their social and political norms. Similarly, Impara (2018) writes that, within radical and extremist movements, violence and religion often go hand-in-hand; such a tendency was noted by Durkheim, who found that violence has often been realized through extreme ascetism, martyrdom, and crusades. One study, which investigated the case of Indonesia's Islamic Defenders Front (Front Pembela Islam, FPI), found that hate speech and demonization are commonly used to justify the movement's attacks on organizations and individuals that it deems sinful or deviant (Woodward et al., 2014). Other studies have shown that acts of violence may be sectarian (Formichi, 2014), sometimes characterized as inter-religious or interethnic (Osaretin \& Akov, 2013).

\subsection{Use of Religion to Legitimize}

Volk (2020) writes that the sources of Islam is sometimes used to legitimize acts of violence. The Qur'an does not command Muslims to perpetrate violence and terrorism, nor does it justify such acts; at the same time, however, the Qur'an does recognize the need to respond to aggression, attacks, and opposition (Esposito, 2015). The history and traditions of Islam are similarly steeped in both peace and violence; indeed, the Prophet Muhammad, who received the Qur'an, led a military campaign (Esposito, 2015). The Qur'an is often held to permit acts of violence when necessary to uphold Islam (Venkatraman, 2007). Similarly, Esposito (2015) writes that the Qur'an obliges Muslims to fight in a jihad, to follow God's plan, and to realize said plan by living well, opposing injustice and subjugation, and promoting social reform. If violence is necessary, it may be accepted. Views of this violence differ significantly. Some Muslims refuse to accept religion as a basis for violence, as seen in Iraq and Afghanistan, while others (as in Pakistan, Nigeria, and Lebanon) perceive religion as precipitating conflict (Religion, 2020).

Those who perpetrate acts of terror and violence against civilians often argue that the Qur'an emphasizes the importance of frightening one's opponents, while Muhammad's life history is replete with examples of violence perpetrated for a sacred cause (Leaman, 2017). Although violence is widespread around the world, many have seen Islam as the most violent religion, citing news coverage of conflict in Palestine (Jews vs. Muslims); the Balkans (Orthodox Serbs vs. Croatian Catholics; Orthodox Serbs vs. Muslim Bosnians and Albanians); Kashmir (Muslims vs. Hindus); Sudan (Muslims vs. Christians and animists); Nigeria and Indonesia (Muslims vs. Christians); Iran, Iraq and Pakistan (Shias vs. Sunnis), Indonesia (Muslims vs. Christians); and Chechnya and the Philippines (Muslim rebellion) (Triandis, 2013). Likewise, entering the word jihad in a search engine returns images of soldiers, swords, and rifles, as well as the flags of extremist Muslim groups (Kaati et al., 2016; Scerri, 2011; Sedgwick, 2015).

\subsection{Islam and Terrorism}

Terrorism is defined as all threats of violence, including text, writing, images, and symbols, that create a sense of fear and limit individuals' freedoms (Nakissa, 2020). Radicalization is another form of religious violence, a phenomenon that has influenced communities around the world, often influencing the faithful to use violence in order to reject the status quo (Baugut \& Neumann, 2020). 
Such radicals have often used the jihad concept to legitimize violence against civilians and spread their religious beliefs (Lenz-Raymann, 2014). Indeed, Venkatraman (2007) notes that terrorists often use the jihad concept to justify their actions, believing that their activities reinforce God's plan and defend the Islamic community.

At its core, terrorism is a political act, one that often involves acts of violence against civilians, and is even perceived by its perpetrators as an act of retribution (Ashford, 2012). Von Sikorski et al. (2017) write that terrorism is commonly linked with radical Islamism, which often understands jihad as involving terror, threats, and violence against Muslims and non-Muslims alike. Kamali (2015) notes that terrorism is often identified with extremism, be it at the local, national, or international level, and that acts of terrorism-including bombings - are destructive acts targeted primarily at civilians. Corbet et al. (2019) define terrorism as the creation of fear and terror through violent acts designed to disrupt the social system. As a result of this terror, discourse have emerged that associate Islam and Islamic practices with terrorism and violence (Holmes, 2017). A major driver of terrorist acts is religious fundamentalism, which perceives religious texts as justifying violence and thus uses said texts to justify terrorist activities (Putra \& Sukabdi, 2014).

\section{Method}

This article examines Qur'anic verses that promote peace and non-violence. This theme is particularly important given the rise of transnational movements that teach extremism, promote radicalism, and even justify terrorist acts. Previous studies have focused on deconstructing that texts used to justify terrorism. This article, conversely, reveals the peaceful and non-violent messages of the Qur'an that have only rarely been discussed.

The main resources used in this study are the Qur'an, exegetical works, and secondary sources (primarily journal articles). After identifying Qur'anic verses through a keyword search, the researchers investigated the implicit/explicit orientation (violent/non-violent) of said verses. Verses that explicitly or implicitly promoted non-violence were subsequent selected and analyzed in terms of their linguistic structure and in terms of their context (sabab a-nuzul); this enabled the researchers to ascertain their meaning. At times, existing exegeses were consulted to obtain a deeper understanding of these verses and their common interpretation. For ease of reading, the selected verses and messages are presented in tables, as are their translations, orientations, and sources.

After data were collected and recorded, content analysis was employed to analyze the verses identified. From this analysis, an understanding of Qur'anic verses and their messages of peace was obtained.

\section{Results}

A spirit of non-violence permeates the Qur'an, and is found both implicitly and explicitly. Many Qur'anic verses express Islam's view of violence, and there exist legal foundations for minimizing violence as well as sanctions for perceived transgressions. At the same time, there are many instances where the Qur'an offers non-violent solutions to social issues.

\subsection{Qur'anic Verses that Promote Non-Violence}

Several elements of the Qur'an can be seen as promoting non-violence and as rejecting violence, as highlighted in Table 1 below:

Table 1: Qur'anic Verses that Promote Non-Violence

\begin{tabular}{|l|l|l|l|}
\hline Verse & Meaning & Orientation & Source \\
\hline $\begin{array}{l}\text { Wamā arsalnāka illā rạ̣mah } \\
\text { li al- 'älamīn }\end{array}$ & $\begin{array}{l}\text { We have sent you 'O Prophet' only as a mercy for the } \\
\text { whole world. }\end{array}$ & $\begin{array}{l}\text { Invitation to bring } \\
\text { mercy to all }\end{array}$ & $\begin{array}{l}\text { Qur'an } \\
\text { 21: } 107\end{array}$ \\
\hline
\end{tabular}




\begin{tabular}{|c|c|c|c|}
\hline Verse & Meaning & Orientation & Source \\
\hline $\begin{array}{l}\text { Ud 'u ilā sabīli rabbika bi al- } \\
\text { hikmah wa al-mau 'izah al- } \\
\text { hasanah wa jādilhum bi al- } \\
\text { latī hiya ahsan }\end{array}$ & $\begin{array}{l}\text { Invite 'all' to the Way of your Lord with wisdom and kind } \\
\text { advice, and only debate with them in the best manner. } \\
\text { Surely your Lord 'alone' knows best who has strayed from } \\
\text { His Way and who is 'rightly' guided. }\end{array}$ & $\begin{array}{l}\text { Wisdom in } \\
\text { communication }\end{array}$ & $\begin{array}{l}\text { Qur'an } \\
16: 125\end{array}$ \\
\hline Lā ikrāha fi al-dīn & Let there be no compulsion in religion & $\begin{array}{l}\text { Freedom of } \\
\text { religion }\end{array}$ & $\begin{array}{l}\text { Qur'an } \\
2: 256\end{array}$ \\
\hline $\begin{array}{l}\text { Walaw shä'a rabbuka } \\
\text { la 'amana rabbuka man fi al- } \\
\text { arḍ kulluhum jamì 'a }\end{array}$ & $\begin{array}{l}\text { Had your Lord so willed 'O Prophet', all 'people' on earth } \\
\text { would have certainly believed, every single one of them! }\end{array}$ & $\begin{array}{l}\text { Recognition of } \\
\text { diversity }\end{array}$ & $\begin{array}{l}\text { Qur'an } \\
\text { 10: } 99\end{array}$ \\
\hline $\begin{array}{l}\text { Qul yā ayyuhā al-kāfirūn, lā } \\
\text { a'bud mā ta budūn }\end{array}$ & $\begin{array}{l}\text { Say, 'O Prophet,' "O you disbelievers! I do not worship } \\
\text { what you worship. }\end{array}$ & Tolerance & $\begin{array}{l}\text { Qur'an } \\
\text { 109: 1-2 }\end{array}$ \\
\hline
\end{tabular}

As evidenced in the above table, the Qur'an contains several verses that implicitly convey a message of non-violence.

First, as shown in the table, the Qur'an understands the Prophet Muhammad as rahmah li al'älamin (a blessing for all), as seen in Qur'an 21: 107. This verse was revealed to guide the Prophet in dealing with the prisoners of war captured during the Battle of Badr, i.e. in deciding whether to kill or free them. Following the revelation of this verse, the prisoners of war were released, pursuant to the recommendations of Abu Bakar (Mahalli, 2002). The word rahmah, which translates to 'mercy' or 'blessing', is often understood as inexorably involving kindness, forgiveness, and goodness (Lukman, 2019). This verse provides a foundation for the concept of Islam as a blessing to the entire universe (Machasin, 2012; Yaqub, 2002); indeed, Mustaqim even understands this blessing as the foundational paradigm of the Qur'an (Mustaqim, 2018; Hannas \& Rinawaty, 2018)

The second verse is Qur'an 16: 125 was revealed as a means of commanding the Prophet to peacefully end the Battle of Uhud (Wāhidī, 1991). This verse emphasizes the use of diverse means of conveying Islam and its messages, including hikmah, al-mau izah al-hasanah, and al-jidäl bi al-latī hiya ahsan. The first method, hikmah, refers to rational and evidence-based arguments that can influence humans' thoughts and feelings. The second, Al-al-mau 'izah al-hasanah, refers to all things that can influence the thoughts and feelings of mankind. Finally, al-jidāl bi al-latī hiya ậsan refers to a refined debate, one that avoids harsh words and violence (Ibn Kathīr, II: 737-738; Baghawi, 1411, V: 52, al-Baidawi, I: 561). According to Chaiwat Satha-Anand, interpretations of this verse have emphasized that these approaches do not permit violence as a means of spreading Islam, but rather rely on patience and understanding (Satha-Anand, 2002). Similar exegeses have been offered for Qur'an 20: 43-44 and its prohibition of khamr (alcohol), particularly its emphasis on implementing the prohibition slowly and adapting to audiences' psychological conditions (Sodiqin, 2017; Istiqomah, 2019).

Third, a prohibition of violence is also found in Qur'an 2: 256 which was revealed in response to Husain's request for permission to force his son to convert from Christianity into Islam (Wahidi, 1991). This verse, by extension, emphasizes the importance of freedom of religion (Shihab, 2002). Indeed, in his book Lä Ikrāha fi al-Dìn (1997), Jawdat Sa'id argues that this verse is a universal one, and that it is no less important than the Throne Verse (Qur'an 2: 255). The main difference, he notes, is that the Throne Verse emphasizes the sacrality of Allah, while Qur'an 2: 256 underscores the need to respect other human beings and protect their religious freedom. This verse may be understood simultaneously as a command (kalam inshā'i) and as a statement (kalām ikhbāri). As a command, it urges Muslims to avoid coercing others into converting to Islam. Meanwhile, as a statement, it emphasizes that nobody can be considered to have truly converted if their hearts continue to reject it (Ghazali: 2012). Similar messages are also found in Qur'an 10: 99 and Qur'an 109: 1-2.

Such prohibitions highlight Islam's abhorrence of violence in all forms, physical and symbolic, as well as its desire to promote peace. 


\subsection{Legal Basis for Non-Violence}

The Qur'an also offers a jurisprudential or legal basis for non-violence, as evident in Table 2 below.

Table 2: Legal Basis for Non-Violence

\begin{tabular}{|c|c|c|c|}
\hline Legal Basis & Meaning & Orientation & Source \\
\hline $\begin{array}{l}\text { Walà tasubbū al-ladhīna yad 'una min } \\
\text { dūn Allāh fa yasubbu Allāh 'adwan } \\
\text { bighair 'ilm }\end{array}$ & $\begin{array}{l}\text { 'O believers!' Do not insult what they invoke besides Allah } \\
\text { or they will insult Allah spitefully out of ignorance. }\end{array}$ & $\begin{array}{l}\text { Prohibition } \\
\text { against hating } \\
\text { other religions }\end{array}$ & $\begin{array}{l}\text { Qur'an } \\
\text { 6: } 108\end{array}$ \\
\hline $\begin{array}{l}\text { Walā taqtulū al-nafs allatī harrama } \\
\text { Allāh illā bi al-ḥaqq, wa man qutila } \\
\text { mažlūman faqad ja 'alnā li waliyyih } \\
\text { șultāna fa lā yușriffi al-qatl innahū kāna } \\
\text { manșūra }\end{array}$ & $\begin{array}{l}\text { Do not take a 'human' life-made sacred by Allah-except } \\
\text { with 'legal' right. If anyone is killed unjustly, We have } \\
\text { given their heirs the authority, but do not let them exceed } \\
\text { limits in retaliation, for they are already supported 'by law'. }\end{array}$ & Right to justice & $\begin{array}{l}\text { Qur'an } \\
\text { 17: } 33\end{array}$ \\
\hline \begin{tabular}{l|} 
Udhina li al-ladhīna yuqātalūna bi \\
annahum zulimū wa inna Allāh 'ala \\
nașrihim laqadīr. Alladhīna ukhrijū min \\
diyārihim bighairi haqq illā an yaqūlu \\
rabbunā Allăh
\end{tabular} & $\begin{array}{l}\text { Permission 'to fight back' is 'hereby' granted to those being } \\
\text { fought, for they have been wronged. And Allah is truly } \\
\text { Most Capable of helping them 'prevail'; 'They are' those } \\
\text { who have been expelled from their homes for no reason } \\
\text { other than proclaiming: "Our Lord is Allah." }\end{array}$ & $\begin{array}{l}\text { Invitation to } \\
\text { peace }\end{array}$ & $\begin{array}{l}\text { Qur'an } \\
\text { 22: } 39- \\
40\end{array}$ \\
\hline $\begin{array}{l}\text { Min ajli dhālik, katabnā 'ala bañ̄ } \\
\text { isrā 'ìla annahū man qatala nafsan } \\
\text { bighairi nafs aw fasād fi al-ard } \\
\text { faka'annamā qatala al-nās jamī ā }\end{array}$ & $\begin{array}{l}\text { That is why We ordained for the Children of Israel that } \\
\text { whoever takes a life-unless as a punishment for murder } \\
\text { or mischief in the land-it will be as if they killed all of } \\
\text { humanity; and whoever saves a life, it will be as if they } \\
\text { saved all of humanity. }\end{array}$ & $\begin{array}{l}\text { Humanity's right } \\
\text { to life }\end{array}$ & $\begin{array}{l}\text { Qur'an } \\
5: 32\end{array}$ \\
\hline
\end{tabular}

As shown in the table above, the Qur'an provides several legal bases for rejecting violence in favor of non-violence.

First, The Qur'an 6: 108 emphasizes that Islam forbids Muslims from insulting non-Muslims for their beliefs. This verse was revealed as Muslims were beginning to insult and otherwise deride the worship activities of non-believers, who responded by insulting the Muslims' God (Yaqub, 1997). To realize this verse, the Prophet introduced the Charter of Medina, a social contract between Muslims and non-Muslims that includes (among other points) that the "Muslims, Jews, and other peoples of Medina are free to embrace their own religion and beliefs. Their freedom of worship is likewise guaranteed" (Embong et al., 2021; Fajriah, 2019). Pursuant to this charter, the people of Medina were not allowed to commit violence against anyone, so long as they were not subjugated to oppression or cruelty. Likewise, non-Muslims could not be coerced into embracing Islam (Hashmi, 2003). This verse shows that the Qur'an is tolerant of and protects minority ethnic and religious groups, and as such promotes diversity while rejecting violence (Huda et al., 2019).

Second, The Qur'an 17: 33 firmly prohibits the killing of others, except in very specific conditions: in times of war and as a form of legal punishment (Shihab, 2002). War is further limited to fights for survival, such as by defending against aggressors where fighting is unavoidable. If a conflict may still be resolved by other means, war is not permitted. In Ahkām al-Qur'ān, Ibn al-'Arabi adds that, in times of war, only adult men may be targeted; women, children, and priests are off limits (Ferdiansyah, 2018). This verse, as with other verses in the Qur'an, emphasizes the need to avoid killing human beings (Qur'an 5:32).

Third, Qur'an 22: 39-40 emphasizes that Muslims may only go to war in order to defend themselves, such as during times of oppression or when facing expulsion. This verse was revealed when the Prophet Muhammad and his companions were being driven away from Mecca (Wahidi, 1991). Mujāhid, al-Ḍaḥhāk, Ibn Abbās, Urwah ibn al-Zubair, Zaid ibn Aslam, Muqātil ibn Ḥayyān, and Qatādah note that this verse was revealed at a time when jihad was necessary. Indeed, this verse was the first one to be revealed that dealt with war, and even then it was evident that jihad was only a final solution, one that could be used only if all other approaches failed-in this case, to deal with the unbelievers of Mecca and their oppressive treatment of the Prophet and his companions (Irawan, 2012). As such, Sahiron understands this verse as one promoting peace (King \& Tan: 2014) 
The verses contained the Qur'an clearly prohibit violence, and allow only defensive war. As such, it can be seen that Islam does not tolerate violence.

\subsection{Qur'anic Verses Providing Peaceful Solutions to Problems}

Islam's non-violence is also evidenced by the verses that offer peaceful solutions to various problems, as noted in the following table:

Table 3: Qur'anic Verses Providing Peaceful Solutions to Problems

\begin{tabular}{|c|c|c|c|}
\hline Verse & Meaning & Orientation & Source \\
\hline $\begin{array}{l}\text { Yã ayyuha al-ladhīna āmanū in jā'akum } \\
\text { făsiq bi naba' fatabayyanū an tușībū } \\
\text { qauman bijahālah fa tuṣbiḥū 'alā mā } \\
\text { fa'altum nādimīn }\end{array}$ & $\begin{array}{l}\text { O believers, if an evildoer brings you any news, verify 'it' } \\
\text { so you do not harm people unknowingly, becoming } \\
\text { regretful for what you have done. }\end{array}$ & Avoiding hoaxes & $\begin{array}{l}\text { Qur'an } \\
\text { 49: } 6\end{array}$ \\
\hline wa shäwirhum fi al-amr & ... and consult with them in 'conducting' matters. & \begin{tabular}{|l|} 
The importance of \\
consultation
\end{tabular} & $\begin{array}{l}\text { Qur'an } \\
\text { 3: } 159 \\
\end{array}$ \\
\hline $\begin{array}{l}\text { Wa in țā'ifatāni min al-mu'minīn } \\
\text { iqtatalū fa așlihū baynahumā fa in } \\
\text { baghat ihdāhumā 'alā al-ukhrā faqāatilū } \\
\text { al-latì tabghì hattā tafi'a ilā amri Allāh }\end{array}$ & $\begin{array}{l}\text { And if two groups of believers fight each other, then } \\
\text { make peace between them. But if one of them } \\
\text { transgresses against the other, then fight against the } \\
\text { transgressing group until they 'are willing to' submit to } \\
\text { the rule of Allah. }\end{array}$ & $\begin{array}{l}\text { Addressing conflict } \\
\text { peacefully }\end{array}$ & $\begin{array}{l}\text { Qur'an } \\
\text { 49: } 9 .\end{array}$ \\
\hline $\begin{array}{l}\text { Wa in khiftum shiqāq bainihimā } \\
\text { fab athū hakaman min ahlihī wa } \\
\text { hakaman min ahlihā }\end{array}$ & $\begin{array}{l}\text { If you anticipate a split between them, appoint a } \\
\text { mediator from his family and another from hers. }\end{array}$ & $\begin{array}{l}\text { The importance of } \\
\text { mediation in times } \\
\text { of conflict }\end{array}$ & $\begin{array}{l}\text { Qur'an } \\
4: 35\end{array}$ \\
\hline
\end{tabular}

Aside from the above-mentioned verses, the Qur'an also contains verses that are oriented towards preventing conflict and violence, or towards employing peaceful solutions to problems. The Qur'an 49: 6 emphasizes the need to verify information from various sources, as well as to seek clarification regarding rumors. This verse was revealed when Ibn al-Walid was asked by the Prophet Muhammad to collect alms (zakat) from the Banu Mustaliq, but claimed that the tribe had threatened to kill him, thereby triggering the anger of Muslims (Wāhidī, 1991; Mahalli, 2002). According to Jawad Mugniah and Kerwanto, this verse clearly prohibits the simple acceptance of information without verification (tabayyun), as doing so could potentially endanger others (Kerwanto, 2018). The need to avoid conflict is also emphasized by Qur'an 24: 12-20. Hoaxes and misinformation have a significant effect, threatening social harmony and solidarity (Sabry, 2018; Afandi, 2018).

The Qur'an 3: 159 emphasizes the importance of employing consultative approaches to overcome various difficulties and resolve diverse conflicts. This verse was revealed at a time when enmities were peaking in Mecca, during the fifth year of Muhammad's prophethood, and many of his companions were forced to evacuate to Habsyah (Ibn Kathīr, n.d., IV: 117; Badri Yatim: 1994). According to Shihab, when this verse was revealed, Muslims lacked any political power, but still had a significant tradition of discourse (Shihab, 2002). This verse is understood as a command to forefront discursive principles in decisionmaking and to avoid violence. This verse is inexorably linked with the principle of mushāwarah, and many have seen democracy as an actualization of this principle (Ichsan, 2014; Ari, 2016; Zaenuri, 2018). The importance of discourse is also emphasized by Qur'an 42:38.

The Qur'an provides Muslims with a means of reconciling individuals and parties in times of conflict, as seen in Qur'an 49: 9. In context, this verse discusses the case of Ummu Zaid, the wife of Imran, who intended to visit her family but whose husband prohibited her from meeting her family. When Ummu Zaid's family arrived to take her away, her husband asked his family to come and stop them. As a result, there occurred significant conflict between their families, including armed fighting. The Prophet Muhammad sent a representative to meet with them and to seek reconciliation (Wahidi, 1991). This verse emphasizes the importance of peaceful mediation, as a means of finding justice and as a means of achieving compromise (Rifa'i, 2010). Mediation is not only offered for social conflict, but also for household disputes, as seen in Qur'an 4:35. 
The verses of the Qur'an show the importance of verifying information, conducting discourse, and resolving conflict through mediation. This shows Islam's emphasis on non-violence and peaceful problem-solving.

\section{Discussion}

This study shows that the Qur'an strongly rejects violence, as seen in three areas. First, non-violence is evident in verses that highlight peace, tolerance, and love, and that prohibit the coercion of others. Second, non-violence is evident in verses that firmly prohibit acts of violence (up to and including warfare). Third, non-violence is evident in verses that urge Muslims to employ peaceful approaches to solving problems, including discussion and mediation, and avoid conflict. Through all three channels, the Qur'an emphasizes non-violence as Islam's universal value. Rather than support terrorism and radicalism, it emphasizes values of peace, tolerance, and non-violence.

Unfortunately, however, the Qur'an's emphasis on non-violence is commonly ignoredespecially by fundamentalists and terrorists, whose understanding of the Qur'an and its verses tends to be partial and superficial. As such, the naskh (abrogation) of verses promoting non-violence is common amongst them, as is the emphasis on the 'verses of the sword' (Wardani, 2016). Exacerbating the situation, these fundamentalists and terrorists' misunderstandings of the Qur'an, as manifested through acts of violence such as suicide bombing, murder, and terrorism, results in Islam being misinterpreted by others (Zuhdi, 2017; M. Abou El Fadl, 2014; Fadilah, 2019). Further misconduct is evident in their abuse of religion and religious interpretations in their social lives-i.e., in their use of religion to justify the persecution of minorities, the destruction of cultural properties, and the prohibition of non-Islamic worship (Rijal, 2017; Perkasa, 2016; Sachedina, 2010)

This study has differed from previous research by emphasizing how Islam views and frames peace. Previous studies of peace in the Qur'an have sought to reinterpret verses that implicitly endorse violence, and that are commonly used to justify acts of violence (Umar, 2014; Arifin, 2015; Abdillah, 2017; Mustaqim, 2018). Conversely, this study has presented Qur'anic verses that explicitly promote non-violent approaches. This article's categorization of Qur'anic verses the diversity of antiviolent messages contained within the sacred text. At the same time, this article has provided a clearer understanding of the substantial messages of Islam as manifested through interrelated verses. Such a thematic approach to interpreting the Qur'an must be enriched by a hermeneutic approach (Malik, 2019; Mohseni, 2014; Zayd, 2004; Syamsuddin, 2018)

By examining the non-violent principles that are explicit and implicit in the Qur'an, a richer methodology is being offered. First, readings of Qur'anic verses may be enriched through a structural understanding of the sacred text's language and explicit message. Second, a reading may offer an understanding of the meanings implicit within them. Analysis must not only consider the linguistic structure of the verse, but also the verse's implications within specific behavioral frameworks. Readings of the Qur'an must be sited within a comprehensive framework of mindsets, values, and behaviors that are structured by the Qur'an through its verses.

To promote the non-violence promoted by the Qur'an, it is necessary for mainstream, moderate to adopt three strategies. First, it is necessary to offer a madrasa curriculum that promotes nonviolence through its lessons and through its orientations (Fitriani, 2015; Prihatin, 2020; Suryadi \& Mansur, 2018). Second, a "public campaign" is necessary to transform non-violence into a shared social understanding and commitment; this could be realized through public discussions, lectures, and social media (Aisy et al., 2019; Lee, 2018). Third, deradicalization policies must recognize and embrace the non-violent values contained within the Qur'an, as this text structures the values embraced by Muslims worldwide (Arifinsyah, Safria Andy, 2020).

\section{Conclusion}

This article has shown that the non-violence promoted by the Qur'an, in three different realms, has 
yet to be optimally recognized. Islam's understanding of peace can be readily socialized by emphasizing these verses, rather than deconstructing those that are commonly understood as promoting violence-as commonly used in efforts to prevent terrorism and fundamentalism.

The above textual analysis has shown the Qur'an contains a multitude of verses that explicitly promote non-violence, and that these verses have been reinforced by extensive exegesis over centuries. Literal understandings of verses that seemingly promote violence can only be combatted by literal understandings of verses that explicitly call for non-violence and non-violent approaches. In such contestation, verses that advocate non-violence can offer a friendlier perspective, a tolerant Islam that is inclusive and civilized. Through its analysis, this article has underscored the peace values within Islam, showing a peace that other scholars have long explored by deconstructing Qur'anic verses with violent implications in order to combat extremism.

This study has been limited to a textual analysis of the Qur'an itself. Its understanding of the verses' social context, however, has been limited to the context in which the text of the Qur'an was revealed. To achieve a deeper understanding of how communities have understood the Qur'an and its text, further research is necessary. Only then can the specific readings of texts, and their relevance within specific social contexts, be elaborated.

\section{References}

Abdillah, J. (2017). Dekonstruksi Tafsir Ayat-Ayat Kekerasan. Analisis: Jurnal Studi Keislaman, 72-90. https://doi.org/10.42042/ANALISIS.V11I1.611

Afandi, I. (2018). Hoax dalam Sejarah Islam Awal (Kajian Kritis Tentang QS. An-Nur : 11-20). Ar-Risalah, Vol. XVI No. $1,16,145-161$.

Aisy, B. R., Ibrahim, D. O., Intang, K. K. H., \& Tindage, M. A. (2019). Penegakan Kontra Radikalisasi Melalui Media Sosial Oleh Pemerintah dalam Menangkal Radikalisme. Jurnal Hukum Magnum Opus, 1-8. https://doi.org/10.30996/jhmo.v2i2.2174

Aisyah, S. (2012). Rereading Patriarchal Interpretations on the Qur'an From Hadith Perspective in the Eve of Law No. 23/2004 on the Elimination of. Jiis.Uinsby.Ac.Id, VI(23).

Ari, A. W. (2016). Syura dan Demokrasi: Antara Teori dan Prakteknya dalam Dunia Islam. Jurnal Ilmu Agama UIN Raden Fatah, 17, 231-240.

Arifin, M. Z. (2015). Deradikalisasi Penafsiran Al-Qur'an. EMPIRISMA, 24, 56-62. https://doi.org/10.30762/empirisma.v24i1.6

Arifinsyah, Safria Andy, A. D. (2020). The Urgency of Religious Moderation in Preventing Radicalism in Indonesia. Esensia, 21, 91-108. https://doi.org/10.14421/esensia.v21i1.2199

Ashford, S. (2012). Terrorism. In R. Chadwick (Ed.), Encyclopedia of Applied Ethics (Second, pp. 334-342). Elsevier Inc. https://doi.org/10.1016/B978-0-12-373932-2.00281-7

Baugut, P., \& Neumann, K. (2020). Online news media and propaganda influence on radicalized individuals: Findings from interviews with Islamist prisoners and former Islamists. New Media and Society. https://doi.org/10.1177/1461444819879423

Chapman, C. (2017). Christian responses to Islamism and violence in the name of Islam. Transformation, 34(2), 115-13o. https://doi.org/10.1177/0265378817695727

Corbet, S., O'Connell, J. F., Efthymiou, M., Guiomard, C., \& Lucey, B. (2019). The impact of terrorism on European tourism. Annals of Tourism Research, 75, 1-17. https://doi.org/10.1016/j.annals.2018.12.012

Dornschneider, S. (2010). Belief systems and action inferences as a source of violence in the name of islam. Dynamics of Asymmetric Conflict: Pathways toward Terrorism and Genocide, 3(3), 223-247. https://doi.org/10.108o/17467586.2010.531748

Embong, Z., Muslim, N., Musa, N. Y., Mohamed, A. F., \& Jusoh, L. M. (2021). Principles of social integration in the constitution of Medina. Academic Journal of Interdisciplinary Studies, 10(1), 382-390. https://doi.org/10.36941/ajis-2021-0032

Esposito, J. L. (2015). Islam and political violence. Religions, 6(3), 1067-1081. https://doi.org/10.3390/rel6031067

Fadilah, A. (2019). Ma'na-Cum-Maghza Sebagai Pendekatan Kontekstual dalam Perkembangan Wacana Hermeneutika Alquran di Indonesia. JOURNAL OF QUR'AN AND HADITH STUDIES.

Fajriah, N. (2019). Kerukunan Umat Beragama: Relevansi Pasal 25 Piagam Madinah dan Pasal 29 UUD 1945. Substantia: Jurnal Ilmu-Ilmu Ushuluddin, 21(2), 162-169. https://doi.org/10.22373/substantia.v21i2.5525 
Fitriani, L. (2015). Pendidikan Peace Building di Pesantren: Sebuah Upaya Mencegah Deradikalisasi. ULUL ALBAB Jurnal Studi Islam, 16(1), 117-130. https://doi.org/10.1886o/ua.v16i1.3011

Formichi, C. (2014). Violence, Sectarianism, and the Politics of Religion: Articulations of Anti-Shi'a Discourses in Indonesia. Indonesia, 98, 1-27. https://doi.org/10.1353/ind.2014.0016

H. M., S. K. (2018). How Violence is Islamized. International Studies. https://doi.org/10.1177/0020881718761768

Hannas, D., \& M.Th., R. (2018). Islam Rahmatan Lil 'Alamin. Journal Kerugma, 1(1), 1-18. https://doi.org/10.33856/kerugma.vii1.50

Hashmi, S. (2003). The Qur'an and tolerance: An interpretive essay on Verse 5:48. Journal of Human Rights, 2(1), 81-103. https://doi.org/10.108o/1475483032000054978

Heller, M. A. (2015). INSS Insight No . 659, January 28, 2015 Islam and Terrorism : A Futile Debate.

Holbrook, D. (2010). Using the Qur ' an to Justify Terrorist Violence : Analysing Selective Application of the Qur ' an in English-Language Militant Islamist Discourse. Perspectives on Terrorism, 4(3), 15-28.

Holmes, J. (2017). Why is the Discourse of 'Islamic Terrorism 'Problematic ? 1-7.

Huda, M. T., Amelia, E. R., \& Utami, H. (2019). Ayat-Ayat Toleransi Dalam Al-Quran Perspektif Tafsir Al-Misbah Dan Tafsir Al-Azhar. Tribakdi.

Ibn Kathīr, Tafsīr Al-Qur'ān al-Aẓìm (2002). Cairo: Dār al-Hadìth.

Ibrahim, N., \& Abdalla, M. (2010). A critical examination of qur'an 4:34 and its relevance to intimate partner violence in muslim families. Journal of Muslim Mental Health, 5(3), 327-349. https://doi.org/10.108o/15564908.2010.551278

Ichsan, M. (2014). Demokrasi dan Syura: Persepektif Islam dan Barat. SUBSTANTIA: Jurnal Ilmu-Ilmu Ushuluddin. https://doi.org/10.22373/SUBTANTIA.V16I1.4913

Impara, E. (2018). A social semiotics analysis of Islamic State's use of beheadings: Images of power, masculinity, spectacle and propaganda. International Journal of Law, Crime and Justice. https://doi.org/10.1016/j.ijlcj.2018.02.002

Irawan, B. (2012). Tafsir Ayat-Ayat Kasih Sayang Dalam Masyarakat Plural. Jurnal THEOLOGIA. https://doi.org/10.2158o/TEO.2012.23.1.176o

Kaati, L., Omer, E., Prucha, N., \& Shrestha, A. (2016). Detecting Multipliers of Jihadism on Twitter. Proceedings 15th IEEE International Conference on Data Mining Workshop, ICDMW 2015. https://doi.org/10.1109/ICDMW.2015.9

Kamali, M. H. (2015). Extremism , Terrorism and Islam : Historical and Contemporary Perspectives. Islam and Civilisational Renewal, 6(2), 148-165. https://doi.org/10.12816/o019163

Karakaya, S. (2015). Religion and Conflict: Explaining the Puzzling Case of "Islamic Violence." International Interactions. https://doi.org/10.1080/03050629.2015.1016158

Kumar, D. (2010). Framing Islam: The resurgence of orientalism during the Bush II era. In Journal of Communication Inquiry. https://doi.org/10.1177/o196859910363174

Leaman, O. (n.d.). Chapter Title: Peace and Violence in Islam: Philosophical Issues Chapter Author ( s ): Oliver Leaman Book Title : Islamic Peace Ethics Book Subtitle : Legitimate and Illegitimate Violence in Contemporary Islamic Thought Book Editor ( $s$ ): Heydar Shadi P.

Lee, F. L. F. (2018). Internet alternative media, movement experience, and radicalism: the case of post-Umbrella Movement Hong Kong. Social Movement Studies. https://doi.org/10.1080/14742837.2017.1404448

Lenz-Raymann, K. (2014). Securitization of Islam: A Vicious Circle. In Securitization of Islam: A Vicious Circle (1st ed.). https://doi.org/10.14361/transcript.9783839429044

Lukman, A. I. (2019). Tafsir Ayat Rahmatan lil 'Alamin Menurut Penafsir Ahlu Sunnah, Muktazilah, Syiah, dan Wahabi. Millah, 15(2), 227-246. https://doi.org/10.20885/millah.vol15.iss2.art3

M. Abou El Fadl, K. (2001). Speaking in God's Name: Islamic Law, Authority and Women. In Oneworld Publications. Oneworld Publications.

Malik, R. K. (2019). Hermeneutika Al-Qur'an dan Debat Tafsir Modern: Implementasinya dengan Masa Kini. ATTURAS: Jurnal Studi Keislaman, 6(1), 56-76. https://doi.org/10.33650/at-turas.v6i1.583

Mohseni, T. (2014). The Comparative Study of Qur'an Interpretation \& Classic Hermeneutics. International Journal of Business and Social Science.

Muluk, H., Sumaktoyo, N. G., \& Ruth, D. M. (2013). Jihad as justification: National survey evidence of belief in violent jihad as a mediating factor for sacred violence among Muslims in Indonesia. Asian Journal of Social Psychology, 16(2), 101-111. https://doi.org/10.1111/ajsp.12002

Munson, Z. (2013). Are Muslims Distinctive?: A Look at the Evidence. Contemporary Sociology: A Journal of Reviews. https://doi.org/10.1177/oo94306112468721k

Mustaqim, A. (2018). De-Radicalization In Quranic Exegesis (Re-Interpretation Of Violence Verses Toward Peaceful Islam). https://doi.org/10.2991/icqhs-17.2018.34 
Nakissa, A. (2020). Security, Islam, and Indonesia. Bijdragen Tot de Taal-, Land- En Volkenkunde / Journal of the Humanities and Social Sciences of Southeast Asia. https://doi.org/10.1163/22134379-bja10004

Osaretin, I., \& Akov, E. (2013). Ethno-Religious Conflict and Peace Building in Nigeria: The Case of Jos, Plateau State. Academic Journal of Interdisciplinary Studies, 2(1), 349-36o. https://doi.org/10.5901/ajis.2013.v2n1p349

Ostebo, T. (2012). Islamic Militancy in Africa. Africa Security Brief.

Perkasa, A. (2016). Kekerasan agama, 2,498 pelanggaran belum dituntaskan. Kabar24.

Pratt, D. (2010). Religion and terrorism: Christian fundamentalism and extremism. Terrorism and Political Violence. https://doi.org/10.1080/o9546551003689399

Prihatin, B. (2020). Peran Madrasah Dalam Membangun Moderasi Agama Di Indonesia Di Era Milineal. Edukasia: Jurnal Pendidikan Dan Pembelajaran.

Putra, I. E., \& Sukabdi, Z. A. (2014). Can islamic fundamentalism relate to nonviolent support? The role of certain conditions in moderating the effect of islamic fundamentalism on supporting acts of terrorism. Peace and Conflict. https://doi.org/10.1037/pacooooo6o

Religion, C. (2020). International Institute of Islamic Thought Sources. 1-20.

Rifa'i, A. (2010). Konflik Dan Resolusinya Dalam Perspektif Islam. Millah, ed(khus), $171-186$. https://doi.org/10.20885/millah.ed.khus.art1o

Rijal, S. (2017). Radikalisme Kaum Muda Islam Terdidik Di Makassar. Al-Qalam. https://doi.org/10.31969/alq.v23i2.434

Sabry, M. S. (2018). Wawasan al-Qur'an tentang hoaks (suatu kajian tafsir tematik). Tafsere.

Sachedina, A. (2010). Religion, World Order, and Peace: A Muslim Perspective. CrossCurrents. https://doi.org/10.1111/j.1939-3881.2010.00134.X

Saiya, N. (2017). Blasphemy and terrorism in the Muslim world. Terrorism and Political Violence, 29(6), 1087-1105. https://doi.org/10.1080/09546553.2015.1115759

Satha-Anand, C. (2002). Forgiveness in Southeast Asia: Political Necessity and Sacred Justifications. Pacifica Review: Peace, Security \& Global Change. https://doi.org/10.1080/1323910022000023101

Scerri, A. (2011). The New Extremism in 21st Century Britain. Politics, Religion E Ideology. https://doi.org/10.1080/21567689.2011.564412

Sedgwick, M. (2015). Jihadism, Narrow and Wide: The Dangers of Loose Use of an Important Term. Perspectives on Terrorism.

Setiawan, T., Scheepers, P., \& Sterkens, C. (2020). Applicability of the social identity model of collective action in predicting support for interreligious violence in Indonesia. Asian Journal of Social Psychology. https://doi.org/10.1111/ajsp.12397

Shihab, M. Q. (2002). TAFSIR AL-MISHBAH Pesan, Kesan dan Keserasian al-Qur'an. In Jakarta: Lentera Hati. https://doi.org/10.1017/CBO9781107415324.004

Sodiqin, A. (2017). Kontinuitas Dan Perubahan Dalam Penetapan Hukum Hudud: Dari Nass Hingga Teks Fikih. Al-Manahij: Jurnal Kajian Hukum Islam. https://doi.org/10.24090/mnh.v10i2.933

Spruyt, B., \& Elchardus, M. (2012). Violence, fear of crime, and Islam scepticism. International Review of Sociology, 22(3), 552-564. https://doi.org/10.1080/03906701.2012.730843

Steven Fish, M., Jensenius, F. R., \& Michel, K. E. (2010). Islam and large-scale political violence: Is there a connection? In Comparative Political Studies (Vol. 43, Issue 11). https://doi.org/10.1177/0010414010376912

Sukma, RizalMa'ruf. (2011). The Attitude of Indonesian Muslims Towards Terrorism: An Important Factor in Counter-terrorism? In Journal of Human Security. https://doi.org/10.3316/JHSo701021

Suryadi, S., \& Mansur, M. (2018). The Role of Traditional Islamic Boarding School-Based Islamic Studies as Radicalism and Intolerance Flow's Blocking Agent. ESENSIA: Jurnal Ilmu-Ilmu Ushuluddin. https://doi.org/10.14421/esensia.v18i2.1483

Syamsuddin, S. (2018). Ma'na-Cum- Maghza Aproach To The Qur'an: Interpretation Of Q. 5:51. https://doi.org/10.2991/icqhs-17.2018.21

Triandis, H. C. (2013). Toward Understanding Violence in Islam. Acta de Investigación Psicológica. https://doi.org/10.1016/s2007-4719(13)70946-3

Umar, N., \& Chusnah, M. (2014). Deradikalisasi Pemahaman Al-Quran Dan Hadis. Aspirasi.

Venkatraman, A. (2007). Religious basis for Islamic terrorism: The Quran and its interpretations. Studies in Conflict and Terrorism. https://doi.org/10.1080/10576100600781612

Volk, T. (2020). Islam - Islamism Clarification for turbulent times. May, o-9.

von Sikorski, C., Matthes, J., \& Schmuck, D. (2018). The Islamic State in the News: Journalistic Differentiation of Islamist Terrorism From Islam, Terror News Proximity, and Islamophobic Attitudes. Communication Research. https://doi.org/10.1177/0093650218803276 
von Sikorski, C., Schmuck, D., Matthes, J., \& Binder, A. (2017). "Muslims are not Terrorists": Islamic State Coverage, Journalistic Differentiation Between Terrorism and Islam, Fear Reactions, and Attitudes Toward Muslims. Mass Communication and Society. https://doi.org/10.1080/15205436.2017.1342131

Wardani, W. (2016). Kekerasan Atas Nama Al-Qur'an: Penganuliran Ayat-ayat Damai dengan Ayat Pedang dan Pengaruhnya dalam Formasi Fiqh Jihad. Jurnal Ilmiah Ilmu Ushuluddin. https://doi.org/10.18592/jiu.v10i2.748

Widiyanto, A. (2017). Violence in Contemporary Indonesian Islamist Scholarship: Habib Rizieq Syihab and 'enjoining good and forbidding evil.' In Islamic Peace Ethics. https://doi.org/10.5771/9783845283494-83

Woodward, M., Yahya, M., Rohmaniyah, I., Coleman, D. M., Lundry, C., \& Amin, A. (2014). The Islamic Defenders Front: Demonization, Violence and the State in Indonesia. Contemporary Islam. https://doi.org/10.1007/s11562-013-0288-1

Zaenuri, A. (2018). Konsep Syura Dan Demokrasi Dalam Al-Qur'an Dalam Pandangan Aktivis Kammi Uin Sunan Kalijaga. Madani Jurnal Pengabdian Ilmiah.

Zayd, N. H. A. (2004). Rethinking the Qur'an: Towards a Humanistic Hermeneutics. In Universiteit voor Humanistiek.

Zuhdi, M. H. (2017). Fundamentalisme Dan Upaya Deradikalisasi Pemahaman Al-Qur'an Dan Hadis. Religia. https://doi.org/10.28918/religia.v13i1.176

Online Web

Ferdiansyah, H. 2018. Benarkah Rasulallah Memerangi Non Muslim Hingga Masuk Muslim. https://bincangsyariah.com/kalam/benarkah-rasulullah-memerangi-non-muslim-hingga-masuk-Islam/

Ghazali, A. 2008. Jaudat Said dan Tafsir La Ikraha Fi al-Din. https://afgani22.wordpress.com/20o8/10/26/jaudatsaid-dan-tafsir-la-ikraha-fi-al-din-oleh-abd-moqsith-ghazali/ 